\title{
Prauserella halophila sp. nov. and Prauserella alba sp. nov., moderately halophilic actinomycetes from saline soil
}

\author{
Wen-Jun Li, ${ }^{1}$ Ping Xu, ${ }^{1}$ Shu-Kun Tang, ${ }^{1}$ Li-Hua Xu, ${ }^{1}$ \\ Reiner M. Kroppenstedt, ${ }^{2}$ Erko Stackebrandt ${ }^{2}$ and Cheng-Lin Jiang ${ }^{1}$
${ }^{1}$ The Key Laboratory for Microbial Resources of Ministry of Education, P. R. China, Laboratory for Conservation and Utilization of Bio-Resources, Yunnan Institute of Microbiology, Yunnan University, Kunming, Yunnan 650091, China
${ }^{2}$ Deutsche Sammlung von Mikroorganismen und Zellkulturen $\mathrm{GmbH}$, Mascheroder Weg 1b, D-38124 Braunschweig, Germany

Correspondence

Cheng-Lin Jiang

lihxu@ynu.edu.cn

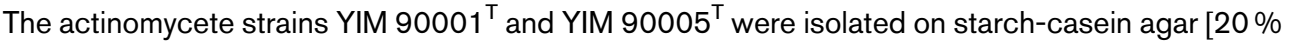
$(\mathrm{w} / \mathrm{v}) \mathrm{NaCl}, \mathrm{pH} 7 \cdot 0$ ] from a soil sample collected from Xinjiang Province in the west of China. The two isolates were aerobic and Gram-positive. The substrate mycelium was fragmented and an aerial mycelium was well developed on Czapek medium. The aerial mycelium formed long spore chains with branched short or long spore chains at maturity, which were straight to flexuous, and spores were non-motile. Based on the results of metabolic, chemotaxonomic and molecular analyses, the two isolates were identified as two new species of the genus Prauserella, for which the names Prauserella halophila for strain YIM $90001^{\top}\left(=\mathrm{DSM} 44617^{\top}=\right.$ CCTCC AA001015 $)$ and Prauserella alba for strain YIM $90005^{\top}\left(=\right.$ DSM $44590^{\top}=$ CCTCC AA001016 $\left.^{\top}\right)$ are proposed.
\end{abstract}

Two actinomycete isolates were isolated from a soil sample collected from hypersaline habitats in Xinjiang Province in the west of China, using starch-casein media $[20 \%(\mathrm{w} / \mathrm{v})$ $\mathrm{NaCl}, \mathrm{pH} 7 \cdot 0$ ] incubated at $28^{\circ} \mathrm{C}$ for about 4 weeks. The strains were maintained on ISP medium 2 and Czapek agar slants (Shirling \& Gottlieb, 1966) at $4{ }^{\circ} \mathrm{C}$ and as glycerol suspensions $(20 \%, \mathrm{v} / \mathrm{v})$ at $-20^{\circ} \mathrm{C}$. Biomass for chemotaxonomic analyses was obtained from growth in broth $(\mathrm{pH} 7 \cdot 2)$ containing glucose $\left(4 \mathrm{~g} \mathrm{l}^{-1}\right)$, yeast extract $\left(4 \mathrm{~g} \mathrm{l}^{-1}\right)$, malt extract $\left(10 \mathrm{~g} \mathrm{l}^{-1}\right)$ and $\mathrm{NaCl}\left(100 \mathrm{~g} \mathrm{l}^{-1}\right)$ at $28{ }^{\circ} \mathrm{C}$. Biomass for molecular systematic studies was obtained by growth in shake flasks (about 150 r.p.m.) using ISP 2 liquid medium $(10 \% \mathrm{NaCl})$ supplemented with vitamin mixtures of the Humic-vitamin medium described by Hayakawa $\&$ Nonomura (1987) at $28^{\circ} \mathrm{C}$ for 3 weeks.

\section{Morphological observations}

Morphological features were observed on Czapek agar $(10 \% \mathrm{NaCl})$ and yeast extract-malt extract (ISP 2 medium; containing $10 \% \mathrm{NaCl}$ ) following incubation for 4 weeks at $28{ }^{\circ} \mathrm{C}$ (Fig. 1). Colour determinations were made by comparing the pure cultures with colour chips from the ISCC-NBS colour charts (standard samples, no. 2106) (Kelly, 1964). Morphology of spores and mycelia was

The GenBank accession numbers for the $16 \mathrm{~S}$ rDNA sequences of


respectively. examined by scanning electron microscopy with a JEOL model JSM5600LV. The substrate mycelia of the two isolates YIM $90001^{\mathrm{T}}$ and YIM $90005^{\mathrm{T}}$ were fragmented, and the aerial mycelia were well developed on Czapek medium. While strain YIM $90001^{\mathrm{T}}$ developed aerial hyphae on most media tested, only Czapek agar supported the formation of an aerial mycelium of strain YIM $90005^{\mathrm{T}}$.

\section{Metabolic properties}

Physiological features were observed on media commonly used for characterization of Streptomyces species (Shirling \& Gottlieb, 1966) prepared with $10 \% \mathrm{NaCl}$. Cultural characteristics were determined after 4 weeks at $28^{\circ} \mathrm{C}$ by using the International Streptomyces Project (ISP) methods (Shirling \& Gottlieb, 1966). The media and procedures used for physiological features and carbon source utilization of the isolates were those described by Shirling \& Gottlieb (1966) and Locci (1989). The metabolic reactions of strains YIM $90001^{\mathrm{T}}$ and YIM $90005^{\mathrm{T}}$ are shown in Table 1. The ranges of carbon and nitrogen utilization of the two strains are wide as they could utilize most carbon and nitrogen sources tested.

\section{Chemotaxonomic properties}

Amino acid and sugar analysis of whole-cell hydrolysates followed procedures described by Staneck \& Roberts (1974). Isoprenoid quinones were extracted and purified using the small-scale integrated procedure of Minnikin et al. (1984). A 

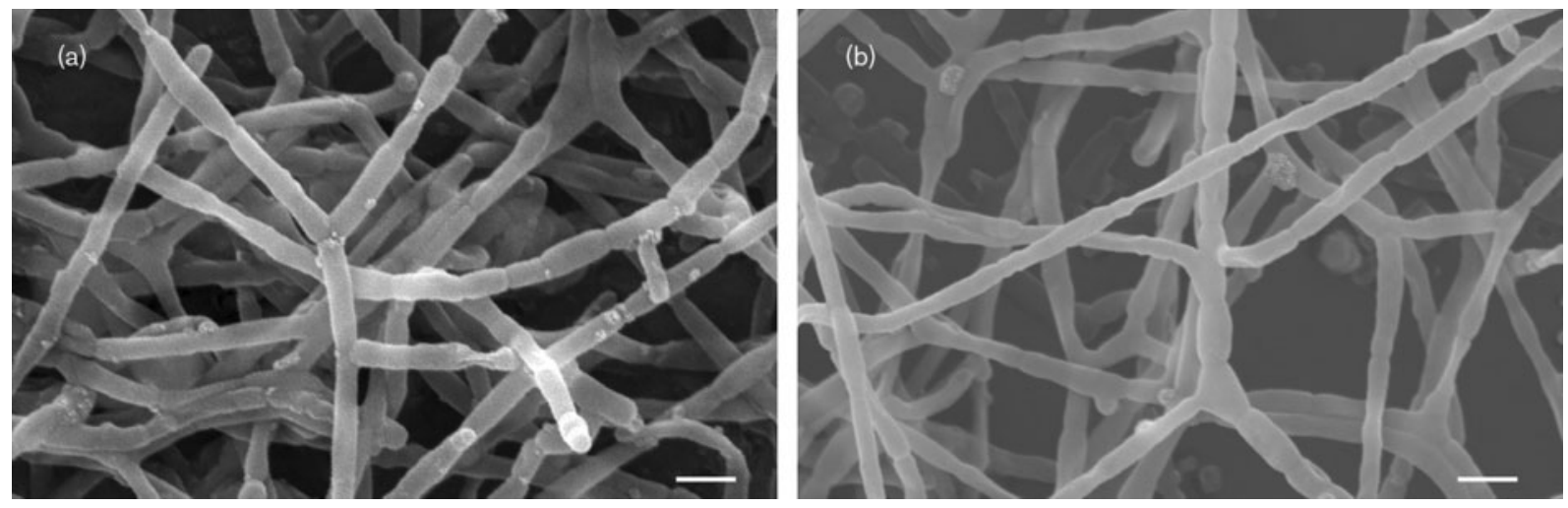

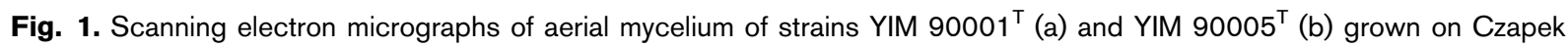
medium, supplemented with $10 \% \mathrm{NaCl}$ for 28 days at $28^{\circ} \mathrm{C}$. Bars, $1 \mu \mathrm{m}$.

dried preparation was dissolved in $200 \mu \mathrm{l}$ 2-propanol and 1-10 $\mu \mathrm{l}$ amounts were injected onto an HPLC column without further purification. The menaquinones were separated on a Lichrosorb RP-18 column $(4 \times 250 \mathrm{~mm})$ kept at $40^{\circ} \mathrm{C}$ with acetonitrile/2-propanol $(65: 35, \mathrm{v} / \mathrm{v})$ as solvent (Kroppenstedt, 1982; Kroppenstedt et al., 1981). Polar lipids were extracted, examined by two-dimensional thin layer chromatography and identified using published procedures (Minnikin et al., 1984). Fatty acid methyl esters were prepared from $40-80 \mathrm{mg}$ wet cells (Miller 1982). The

Table 1. Comparison of morphological, physiological and chemical characteristics of strains

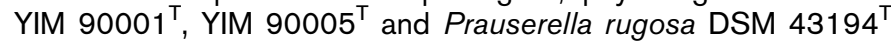

All strains utilize cellobiose, fructose, glucose, mannitol, rhamnose, ribose, sucrose, xylitol and xylose, and L-alanine and L-proline as nitrogen source. All strains are negative for milk peptonization, starch hydrolysis, cellulose degradation, nitrate reduction, $\mathrm{H}_{2} \mathrm{~S}$ production and melanin production.

\begin{tabular}{|c|c|c|c|}
\hline Characteristic & YIM $90001^{\mathrm{T}}$ & YIM $90005^{T}$ & $\begin{array}{l}\text { Prauserella rugosa } \\
\text { DSM } 43194^{\mathrm{T}}\end{array}$ \\
\hline Aerial mycelium & + & + & - \\
\hline Spore formation & + & + & - \\
\hline Range of $\mathrm{NaCl}$ concentration for growth (\%) & $5-25$ & $0-25$ & $0-20$ \\
\hline Optimal growth concentration of $\mathrm{NaCl}(\%)$ & $10-15$ & $10-15$ & $5-10$ \\
\hline Gelatin liquefaction & + & + & - \\
\hline Milk coagulation & + & + & - \\
\hline Urease production & + & - & - \\
\hline Dehalogenase activity & - & + & - \\
\hline \multicolumn{4}{|l|}{ Carbon utilization: } \\
\hline Arabinose & - & + & + \\
\hline Galactose & - & + & + \\
\hline Maltose & - & + & + \\
\hline Trehalose & ND & - & + \\
\hline Inositol & + & + & - \\
\hline \multicolumn{4}{|l|}{ Nitrogen utilization: } \\
\hline L-Arginine & + & + & - \\
\hline Asparagine & + & + & - \\
\hline Histamine & + & + & - \\
\hline Hydroxyproline & + & + & - \\
\hline L-Serine & + & + & - \\
\hline L-Threonine & + & + & - \\
\hline Major menaquinone & $9\left(\mathrm{H}_{4}\right)$ & $9\left(\mathrm{H}_{4}\right)$ & $9\left(\mathrm{H}_{2}, \mathrm{H}_{4}\right)$ \\
\hline DNA G $+\mathrm{C}$ content $(\mathrm{mol} \%)$ & $65 \cdot 8$ & $66 \cdot 7$ & $67-68 \cdot 9$ \\
\hline
\end{tabular}


extracts of the methanolysates were analysed by the MIDI microbial identification system as described by Sasser (1990). The results of chemotaxonomic investigations were compared with the data of Prauserella rugosa DSM $43194^{\mathrm{T}}$ (Kim \& Goodfellow, 1999). Analyses of whole-cell amino acids and sugars revealed meso-diaminopimelic acid and arabinose plus galactose for strains YIM $90001^{\mathrm{T}}$ and YIM $90005^{\mathrm{T}}$, as expected for members of the genus Prauserella (Lechevalier et al., 1986). The main menaquinone was MK-9 $\left(\mathrm{H}_{4}\right)$ for all three strains. The fatty acid composition of the two isolates is similar to that reported for Prauserella rugosa (Mertz \& Yao, 1993). Hydroxyphosphatidylethanolamine and hydroxymethylphosphatidylethanolamine, present in Prauserella rugosa DSM $43194^{\mathrm{T}}$ (Yassin et al., 1993), were missing in strains YIM $90001^{\mathrm{T}}$ and YIM $90005^{\mathrm{T}}$.

\section{Molecular analyses}

Methods for genomic DNA extraction, PCR of the $16 \mathrm{~S}$ rRNA genes and the sequencing primers used were as described by Cui et al. (2001). For the phylogenetic analyses, reference strains were chosen from BLAST (Altschul et al., 1997) search results. Multiple alignments of the sequences determined in this study, together with reference sequences obtained from databases and calculations of levels of sequence similarity were carried out using CLUSTAL W 1.8 (Thompson et al., 1994). The phylogenetic tree was reconstructed using the neighbour-joining method of Saitou \& Nei (1987) based upon $K_{\text {nuc }}$ values of Kimura $(1980,1983)$. The topology of the phylogenetic tree was evaluated by the bootstrap resampling method of Felsenstein (1985) with 1000 replicates. The accession numbers of the reference strains are listed in Fig. 2.

Chromosomal DNA was prepared following the method of Marmur (1961). The G+C content of the DNA of the test strains was determined using the thermal denaturation method of Marmur \& Doty (1962). DNA-DNA hybridization was carried out according to published methods (De Ley et al., 1970; Huss et al., 1983; Jahnke, 1992).

The almost complete 16S rRNA gene sequences of strains YIM $90001^{\mathrm{T}}$ and YIM $90005^{\mathrm{T}}$ were first analysed by a BLAST search and secondly by a more detailed similarity search with sequences of the strains shown in Fig. 2. The neighbour-joining tree indicated that strains YIM $90001^{\mathrm{T}}$ and YIM $90005^{\mathrm{T}}$ were highly related $(99 \cdot 0 \%$ sequence similarity) and both strains were close to the type strain Prauserella rugosa DSM $43194^{\mathrm{T}}(97 \cdot 57$ and $97 \cdot 78 \%$ sequence similarity, respectively), forming a distinct branch within the family Pseudonocardiaceae (Stackebrandt et al., 1997). Strains YIM $90001^{\mathrm{T}}$ and YIM $90005^{\mathrm{T}}$ have no more than $96 \%$ sequence similarity to members of this family.

The $\mathrm{G}+\mathrm{C}$ contents of the genomic DNAs from strains YIM $90001^{\mathrm{T}}$ and YIM $90005^{\mathrm{T}}$ were $65 \cdot 8$ and $66 \cdot 7 \mathrm{~mol} \%$, respectively.

DNA-DNA reassociation experiments indicated a low value of $35.4 \%$ similarity between strains YIM $90001^{\mathrm{T}}$ and YIM $90005^{\mathrm{T}}$, while the similarity values for these two strains and Prauserella rugosa DSM $43194^{\mathrm{T}}$ were 5 and $35.4 \%$ respectively.

\section{Taxonomic conclusions}

Based on phylogenetic analyses and chemotaxonomic properties the two isolates YIM $90001^{\mathrm{T}}$ and YIM $90005^{\mathrm{T}}$ should be considered members of the genus Prauserella. Both strains YIM $90001^{\mathrm{T}}$ and YIM $90005^{\mathrm{T}}$ differ in morphology from P. rugosa DSM $43194^{\mathrm{T}}$ (Kim \& Goodfellow, 1999). The substrate mycelium is fragmented and the aerial mycelium is well developed. The aerial mycelium forms long spore chains with branched short or long spore chains at maturity, which are straight to flexuous, and spores are non-motile. DNA-DNA relatedness provided important data for determining the taxonomic position of the new isolates. DNA-DNA hybridization among the two new isolates and P. rugosa DSM $43194^{\mathrm{T}}$ revealed significantly lower than $70 \%$ similarity values, indicating that strains YIM $90001^{\mathrm{T}}$ and YIM $90005^{\mathrm{T}}$ represent two new species in accordance with the recommendations of the committee on reconciliation of approaches to bacterial systematics (Wayne et al., 1987). As the genomic distinctness is also expressed by differences in some metabolic properties (Table 1), we propose the names Prauserella halophila sp. nov. and Prauserella alba sp. nov. for strains YIM $90001^{\mathrm{T}}$ and YIM $90005^{\mathrm{T}}$, respectively.

\section{Emendation of the genus Prauserella Kim \& Goodfellow 1999}

The genus description (Kim \& Goodfellow, 1999) is emended with respect to morphology and the chemical composition of cell constituents.

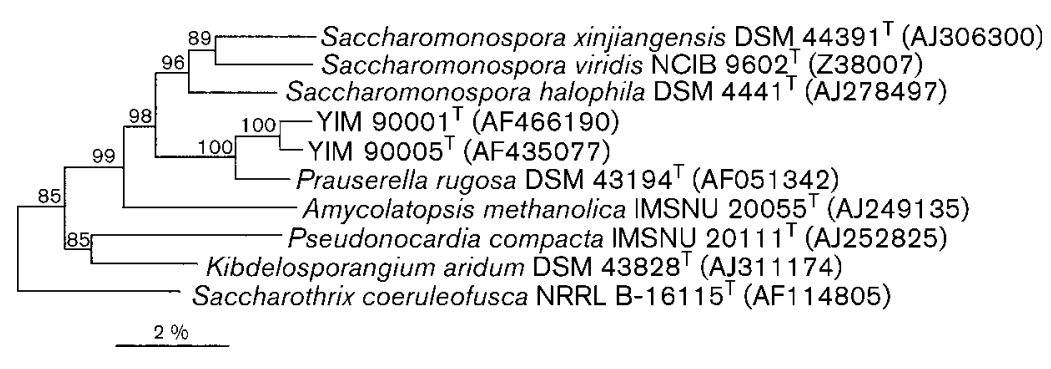

Fig. 2. Phylogenetic tree obtained by the neighbour-joining method showing the posi-

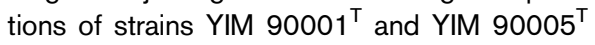
among phylogenetically related members of the family Pseudonocardiaceae. Numerals on branches are bootstrap values (1000 replicates, only values $>50 \%$ are indicated). Bar, 2 nt substitutions per 100 nt $16 S$ rDNA sequence. The sequence of Streptosporangium roseum was used as outgroup. 
Aerobic, Gram-positive, non-acid-alcohol-fast, non-motile actinomycetes that form an extensively branched substrate mycelium $(0 \cdot 6-0.8 \mu \mathrm{m}$ in diameter $)$ which fragments into irregular rods within $24-48 \mathrm{~h}$ on rich medium. Aerial hyphae with straight to flexuous spore chains may be formed which are short and branched, or, at maturity, are long. Spores are non-motile. Brownish, soluble pigment may be produced on some media. Some strains grow optimally at $10 \%$ or between 10 and $15 \% \mathrm{NaCl}$ at $28{ }^{\circ} \mathrm{C}$ and $\mathrm{pH} 7 \cdot 0$. Optimal growth between $\mathrm{pH} 6 \cdot 8$ and $7 \cdot 2$. The temperature range for growth is $10-45^{\circ} \mathrm{C}$, with the optimum temperature at 28 or $34^{\circ} \mathrm{C}$. Mycolic acid absent. Contains mesodiaminopimelic acid as the diamino acid, an acetylated peptidoglycan (only one species tested), major amounts of arabinose and galactose (some strains also ribose), di- and tetrahydrogenated menaquinones with nine isoprenoid units or tetrahydrogenated menaquinones with nine isoprenoid units as the predominant isoprenologue. Diphosphatidylglycerol, phosphatidylglycerol and phosphatidylethanolamine are diagnostic polar lipids; some strains also contain phosphatidylinositol and methylphosphatidylethanolamine. Fatty acid profile is rich in branched-chain and saturated components. The $\mathrm{G}+\mathrm{C}$ content of DNA ranges between $65 \cdot 8$ and $69 \cdot 9 \mathrm{~mol} \%$ ( $T_{\mathrm{m}}$ method). The genus belongs to the family Pseudonocardiaceae. The type species is Prauserella rugosa.

\section{Description of Prauserella halophila sp. nov.}

Prauserella halophila (ha.lo' phi.la. Gr. n. halo salt; Gr. adj. phila loving; N.L. gen. adj. halophila salt-loving, referring to the ability to grow at high $\mathrm{NaCl}$ concentrations).

Gram-positive and aerobic. The branched substrate mycelium is fragmented, the colour ranging from light greywhite (ISP 5), deep grey-white (ISP 3), light yellow (ISP 2 and 4), deep yellow (potato agar), or light orange-brown (Czapek's agar), all media being prepared with $10 \% \mathrm{NaCl}$. A white to yellow aerial mycelium is well developed on most media tested (except for ISP 2), forming branched short or, at maturity, long spore chains, which are straight to flexuous. Spores non-motile. No diffusible pigment produced. Optimum growth occurs on Czapek media supplemented with $\mathrm{NaCl}$ at a concentration of $10-15 \%$ at $28^{\circ} \mathrm{C}$ and $\mathrm{pH} 7 \cdot 0$. The range of carbon and nitrogen utilization of strain YIM $90001^{\mathrm{T}}$ is wide (Table 1). Galactose, arabinose and ribose are found in whole-cell hydrolysates. The main menaquinone is MK- $9\left(\mathrm{H}_{4}\right)(83 \%)$ and small amounts of MK- $8\left(\mathrm{H}_{4}\right)(4 \%)$, MK-9 (5\%) and MK-9 $\left(\mathrm{H}_{2}\right)(8 \%)$ are also found. Polar lipids are phosphatidylinositol, phosphatidylglycerol, diphosphatidylglycerol, phosphatidylethanolamine and methylphosphatidylethanolamine. The major cellular fatty acids are iso/anteiso-branched fatty acids: iC16:0 (27\%), cis-11C17: 1 (11\%), cis-9C16:1 (11.0\%), aiC17:0 (10.6\%), cis-9C17:1 (8.7\%), C16:0 (8\%), iC16: 1 (4.1\%), C17:0 (3.9\%), cis-xC18: 1 (3.7\%), $\mathrm{C} 15: 0(2 \cdot 2), \mathrm{C} 15: 1(2 \cdot 2 \%)$, cis-9C18:1 $(2 \cdot 2 \%)$, iC17:0 $(1.6 \%)$, iC15:0 (1.8\%), aiC15:0 (1.3\%) and $\mathrm{iC} 14: 0$ $(1 \cdot 2 \%)$. The $\mathrm{G}+\mathrm{C}$ content of the DNA is $65 \cdot 8 \mathrm{~mol} \%$.
Isolated from soil in hypersaline habitats, Xinjiang Province in the west of China. Type strain is YIM $90001^{\mathrm{T}}$, deposited in the Chinese Centre of Type Culture Collection as strain CCTCC AA001015 ${ }^{\mathrm{T}}\left(=\mathrm{DSM} 44617^{\mathrm{T}}\right)$.

\section{Description of Prauserella alba sp. nov.}

Prauserella alba (al'ba. L. adj. alba white, referring to the white aerial mycelium).

The branched substrate mycelium is fragmented, the colour ranging from yellow-white and light yellow (nutrient agar, ISP 4, ISP 5), light orange-yellow (Czapek's agar, potato agar), orange-yellow (ISP 2) and grey-white (ISP 3), all media being prepared with $10 \% \mathrm{NaCl}$. A white aerial mycelium developed on Czapek medium, forming branched short or, at maturity, long spore chains, which were straight to flexuous; spores non-motile. No diffusible pigment. Optimum growth occurs in Czapek medium supplemented with $\mathrm{NaCl}$ at a concentration of $10 \%$ at $28{ }^{\circ} \mathrm{C}$ and $\mathrm{pH} 7 \cdot 0$. It can utilize a broad range of carbon and nitrogen sources (Table 1). Galactose, arabinose and ribose are found in whole-cell hydrolysates. Main menaquinone is $\mathrm{MK}-9\left(\mathrm{H}_{4}\right)$ $(90 \%)$; MK- $9\left(\mathrm{H}_{2}\right)$ occurs in smaller amounts $(8 \%)$. Traces of MK-8 $\left(\mathrm{H}_{4}\right)$ and MK-9 are found in addition. Polar lipids are phosphatidylinositol, phosphatidylglycerol, diphosphatidylglycerol, phosphatidylethanolamine and methylphosphatidylethanolamine. The major cellular fatty acids are iso/anteiso-branched fatty acids. Traces of 10-methylbranched fatty acids are also found. The principal fatty acids are: $\mathrm{iC} 16: 0$ (29\%), cis-11C17: $1(8 \cdot 7 \%)$, cis-9C16:1 $(8 \cdot 1 \cdot 0 \%)$, aiC17:0 (10.5\%), cis-9C17:1 (5.3\%), C16:0 $(8 \cdot 7 \%), \quad \mathrm{iC} 16: 1 \quad(6 \cdot 8 \%), \quad \mathrm{C} 17: 0 \quad(2 \cdot 09 \%)$, cis-xC18: 1 $(7 \cdot 0 \%), \quad$ C15:1 $(2 \cdot 2 \%)$, cis-9C18: $1 \quad(4 \cdot 2 \%), \quad \mathrm{iC} 15: 0$ $(2 \cdot 2 \%)$ and $\mathrm{iC} 17: 0(3 \cdot 0 \%)$. The $\mathrm{G}+\mathrm{C}$ content of the DNA is $66.7 \mathrm{~mol} \%$. Isolated from soil in hypersaline habitats, Xinjiang Province in the west of China. Type strain is YIM $90005^{\mathrm{T}}$, deposited in the Chinese Centre of Type Culture Collection as strain CCTCC AA001016 $\left(=\operatorname{DSM} 44590^{\mathrm{T}}\right)$.

\section{Acknowledgements}

We thank Bettina Sträubler for DNA-DNA reassociation experiments. This research was supported by the Ministry of Science and Technology, P. R. China (Project no. 2002C0001P), National Natural Science Foundation of China (Project no. 30270004), the Key Laboratory for Microbial Resources of Ministry of Education, P. R. China and Yunnan Provincial Natural Science Foundation (Project no. 2001C0001Q) and Yunnan Provincial Educational Administration.

\section{References}

Altschul, S. F., Madden, T. L., Schäffer, A. A., Zhang, J., Zhang, Z., Miller, W. \& Lipman, D. J. (1997). Gapped BLAST and PSI-BLAST: a new generation of protein database search programs. Nucleic Acids Res 25, 3389-3402.

Cui, X. L., Mao, P. H., Tseng, M., Li, W. J., Zhang, L. P., Xu, L. H. \& Jiang, C. L. (2001). Streptomonospora salina gen. nov., a new member of the family Nocardiopsaceae. Int J Syst Evol Microbiol 51, 357-363. 
De Ley, J., Cattoir, H. \& Reynaerts, A. (1970). The quantitative measurement of DNA hybridization from renaturation rates. Eur J Biochem 12, 133-142.

Felsenstein, J. (1985). Conference limits on phylogenies: an approach using the bootstrap. Evolution 39, 783-789.

Hayakawa, M. \& Nonomura, H. (1987). Humic acid-vitamin agar, a new medium for the selective isolation of soil actinomycetes. J Ferment Technol 65, 501-509.

Huss, V. A. R., Festl, H. \& Schleifer, K.-H. (1983). Studies on the spectrophotometric determination of DNA hybridization from renaturation rates. Syst Appl Microbiol 4, 184-192.

Jahnke, K.-D. (1992). BASIC computer program for evaluation of spectroscopic DNA renaturation data from Gilford System 2600 spectrophotometer on a PC/XT/AT type personal computer. J Microbiol Methods 15, 61-73.

Kelly, K. L. (1964). Inter-Society Color Council-National Bureau of Standards Color-Name Charts Illustrated with Centroid Colors. Washington, DC: US Government Printing Office.

Kim, S. B. \& Goodfellow, M. (1999). Reclassification of Amycolatopsis rugosa Lechevalier et al. 1986 as Prauserella rugosa gen. nov., comb. nov. Int J Syst Bacteriol 49, 507-512.

Kimura, M. (1980). A simple method for estimating evolutionary rates of base substitutions through comparative studies of nucleotide sequence. J Mol Evol 16, 111-120.

Kimura, M. (1983). The Neutral Theory of Molecular Evolution. Cambridge: Cambridge University Press.

Kroppenstedt, R. M. (1982). Separation of bacterial menaquinones by HPLC using reverse phase (RP 18) and a silver loaded ion exchanger as stationary phases. J Liquid Chromatogr 5, 2359-2387.

Kroppenstedt, R. M., Korn-Wendisch, F., Fowler, V. J. \& Stackebrandt, E. (1981). Biochemical and molecular genetic evidence for transfer of Actinoplanes armeniacus into the family Streptomycetaceae. Zentbl Bakteriol Mikrobiol Hyg 1 Abt Orig C 2, 254-262.

Lechevalier, M. P., Prauser, H., Labeda, D. \& Ruan, J. S. (1986). Two new genera of nocardioform actinomycetes: Amycolata gen. nov. and Amycolatopsis gen. nov. Int J Syst Bacteriol 36, 29-37.

Locci, R. (1989). Streptomyces and related genera. In Bergey's Manual of Systematic Bacteriology, Vol. 4, pp. 2463-2468. Edited by S. T. Williams, M. E. Sharpe \& J. G. Holt. Baltimore: Williams \& Wilkins.
Marmur, J. (1961). A procedure for the isolation of deoxyribonucleic acid from microorganisms. J Mol Biol 3, 208-218.

Marmur, J. \& Doty, P. (1962). Determination of base composition of deoxyribonucleic acid from its denaturation temperature. J Mol Biol 5, 109-118.

Mertz, F. P. \& Yao, R. C. (1993). Amycolatopsis alba sp. nov., isolated from soil. Int J Syst Bacteriol 43, 715-720.

Miller, L. T. (1982). A single derivatization method for bacterial fatty acid methyl esters including hydroxy acids. J Clin Microbiol 16, 584-586.

Minnikin, D. E., O'Donnell, A. G., Goodfellow, M., Alderson, G., Athalye, M., Schaal, A. \& Parlett, J. H. (1984). An integrated procedure for the extraction of isoprenoid quinones and polar lipids. J Microbiol Methods 2, 233-241.

Saitou, N. \& Nei, M. (1987). The neighbor-joining method: a new method for reconstructing phylogenetic trees. Mol Biol Evol 4, 406-425.

Sasser, M. (1990). Identification of bacteria by gas chromatography of cellular fatty acids. USFCC Newsl 20, 1-6.

Shirling, E. B. \& Gottlieb, D. (1966). Methods for characterization of Streptomyces species. Int J Syst Bacteriol 16, 313-340.

Stackebrandt, E., Rainey, F. A. \& Ward-Rainey, N. L. (1997). Proposal for a new hierarchic classification system of Actinobacteria classis nov. Int J Syst Bacteriol 47, 479-491.

Stanek, J. L. \& Roberts, G. D. (1974). Simplified approach to identification of aerobic actinomycetes by thin layer chromatography. Appl Microbiol 28, 226-231.

Thompson, J. D., Higgins, D. G. \& Gibson, T. J. (1994). CLUSTAL W: improving the sensitivity of progressive multiple sequence alignment through sequence weighting, positions-specific gap penalties and weight matrix choice. Nucleic Acids Res 22, 4673-4680.

Wayne, L. G., Brenner, D. J., Colwell, R. R. \& 9 other authors (1987). International Committee on Systematic Bacteriology. Report of the ad hoc committee on reconciliation of approaches to bacterial systematics. Int J Syst Bacteriol 37, 463-464.

Yassin, A. F., Haggenei, B., Budzikiewicz, H. \& Schaal, K. P. (1993). Fatty acid and polar lipid composition of the genus Amycolatopsis: Application of fast atom bombardment-mass spectrometry to structure analysis of underivatized phospholipids. Int J Syst Bacteriol 43, 414-420. 